O.O.Григор,

кандидат наук з державного управління,

дочент ЧДТУ

\title{
БАГАТОСТОРОННЯ ДИПЛОМАТІЯ ЯК ЧИННИК УРЕГУЛЮВАННЯ МІЖНАРОДНИХ КОНФЛІКТІВ І КРИЗОВИХ СИТУАЦІЙ
}

У наш час політична й економічна взаємозалежність держав та глобалізаційні процеси в світі впливають на інтереси відразу кількох відносно незалежних учасників міжнародних відносин. Якщо в період до Першої світової війни дипломатична діяльність здійснювалась, головним чином, на двосторонній основі шляхом обміну посольськими місіями, то на сьогодні дипломатія значною мірою має багатосторонній характер, який передбачає участь понад двох сторін в обговоренні та розв'язанні проблемних питань. Як наслідок у світовій дипломатії сформувався такий напрям, як багатостороння дипломатія.

Розвиток багатосторонньої дипломатії, зокрема багатосторонніх перемов, зумовлений тим, що він відкриває можливості для колективного управління взаємозалежністю. У другій полонит XX ст. форми багатосторонньої дипломатії набирали широкої різноманітності. Якщо в минулому вона здійснювалася переважно у формі переговорного процесу в рамках різних конгресів (наприклад, Вестфальський конгрес 1648 р., Карловицький конгрес 1698-1699 pp., Віденський конгрес 1815 р. та ін., то на сьогодні багатостороння дипломатія провадиться в рамках: міжнародних універсальних $(\mathrm{OOH})$ і регіональних (ЄС, ОБСС, ЛАД) організацій; конференцій, комісій та ін., які створюють або скликають для вирішення тієї чи іншої проблеми (наприклад, Паризька конференція з питань В'єтнаму, Спільна комісія 3 урегулювання конфлікту в Південно-Західній Африці); багатосторонніх зустрічей на найвищому рівні, зокрема, зустрічі лідерів країн так званої «великої вісімки» («G48») восьми провідних країн світу; діяльності посольств окремих держав (наприклад, посольство США у КНР спільно з китайськими та японськими дипломатами приділяло особливу увагу пошуку рішень проблем на Корейському півострові. Аналогічні заходи запроваджуються 
американськими дипломатами спільно з дипломатичними представниками інших країн (зокрема, Латинської Америки, Центральної та Південної Африки).

Багатостороння дипломатія та багатосторонні перемови створюють передумови для виникнення низки нових моментів у дипломатичній практиці. Так, збільшення кількості сторін у ході обговорення проблеми призводить до ускладнення загальної структури інтересів, можливості створення коаліцій, а також появи країнилідера на переговорних форумах. Крім цього, на міжнародних перемовах майже завжди виникає ціла низка організаційних, процедурних та технічних проблем, пов'язаних, наприклад, із погодженням порядку денного перемов, місця їх проведення, опрацюванням та ухваленням рішень, головуванням на форумах, розміщенням делегацій, забезпеченням їх необхідними умовами для роботи, копіювальною та іншою технікою, автотранспортом та ін. Все це, своєю чергою, спричиняє бюрократизацію переговорних процесів, особливо тих, в яких права здійснюються в рамках міжнародних організацій $[1,24]$.

Глобалізація та взаємопов'язаність світу призвели також до зростання ролі дипломатії на високому та найвищому рівнях. Названий вид дипломатії дав змогу протягом другої половини ХХ ст. та початку XXI ст. ухвалювати справді кардинальні рішення з найнагальніших міжнародних проблем і відтак різко змінювати міжнародну ситуацію. Одним із останніх яскравих прикладів вищезазначеного $\epsilon$ врегулювання загострення грузинсько-південноосетинського та грузинсько-абхазького конфліктів шляхом негайного проведення двосторонніх перемов на найвищому рівні та затвердження президентами Російської Федерації, Грузії та Франції так званого Плану «Медведєва-Саркозі» влітку 2008 року.

Крім цього, дипломатія на високому та найвищому рівнях дає можливість взаємопов'язувати обговорення широкого спектра питань, що є майже неможливим під час проведенні зустрічей на інших рівнях $[1,24]$.

В умовах глобалізації необхідним є не тільки вдосконалення традиційно використовуваних інструментів і засобів міжнародної співпраці, а й активний пошук нових форм, методів та інституцій міжнародного партнерства, які б адекватно відповідали змінам і розвитку зовнішніх торговельно-економічних зв'язків та формували б механізм ефективного врегулювання проблем, що постійно 
виникають. Систему таких інструментів і засобів становить саме економічна дипломатія, роль та значення якої останніми роками суттєво зросли [2].

Економічна дипломатія - це офіційна діяльність спеціальних органів зовнішніх відносин зі здійснення цілей і вирішення завдань зовнішньої політики держав, а також захисту прав та інтересів держав за кордоном. Активізація економічної дипломатії як одного 3 важливих інструментів зовнішньоекономічної політики країни в контексті загальносвітових тенденцій економізації зовнішньої політики зумовлена низкою факторів, серед яких слід відзначити: загальне збільшення обсягів світової економіки та глобалізацію сучасної економіки (лібералізація умов здійснення економічних операцій та посилення їх транскордонного та наднаціонального характеру); загострення глобальних проблем (продовольча безпека, зміна клімату, охорона навколишнього середовища, загальносвітові епідемії, міжнародний тероризм тощо), вирішення яких потребує значних матеріальних ресурсів, акумуляція та використання яких, своєю чергою, потребують міжнародної співпраці; появу та активну роль у світовій економіці нових субнаціональних акторів (передусім - транснаціональних корпорацій, громадських організацій та ін.); розвиток регіональних економічних інтеграційних об'єднань; підвищення політичного впливу національного капіталу в країнах, які намагаються відігравати помітну роль у світовій політичній та економічній системі [3].

Основним ініціатором розвитку економічної дипломатії виступили США. Економізація зовнішньої політики цієї країни почала помітно посилюватися після певного періоду її вимушеної «мілітаризації», по завершенні періоду «холодної війни». Значну роль у цьому відіграла ініціатива тодішнього заступника державного секретаря США Л.Ігелбергера (відома, як «Ігелбергівський «Біль про права»), оприлюднена в листопаді 1989 року. Сутність цієї ініціативи полягала у визнанні першочерговим національним інтересом США підтримку розвитку їх економіки. 3 метою збільшення ролі Державного департаменту в просуванні інтересів американських компаній за кордоном та нівелювання конкурентних переваг, що отримують компанії інших країн від власних урядів, Л.Ігелбергер запропонував визнати за американськими господарюючими суб'єктами права на: врахування їхньої позиції в ході формування зовнішньої 
політики; надання їм сприяння у встановленні рівних і недискримінаційних умов у міжнародній торгівлі; отримання кваліфікованої допомоги від фахівців у всіх закордонних дипломатичних установах; отримання професійних порад і аналізу умов місцевого політичного і ділового середовища; надання сприяння у встановленні контактів 3 ключовими державними і приватними центрами прийняття рішень; рівну для всіх зацікавлених американських фірм підтримку під час участі в міжнародних торгах; допомогу в розв'язанні інвестиційних і ділових спорів, а в разі експропріації - допомогу в отриманні швидкої і повної компенсації.

Початок XXI сторіччя поставив перед дипломатією низку нових проблем, пов'язаних із гуманітарним втручанням у конфлікти, перебудовою діяльності міжнародних організацій, примусом до миру (до речі, так називалася збройна операція військових формувань Російської Федерації проти збройних сил Грузії у зоні грузинсько-південноосетинського конфлікту влітку 2008 року). Урегулювання міжнародних конфліктів та кризових ситуацій - одне 3 найактуальніших завдань сучасної дипломатії. Австралійський дослідник Дж. Річардсон пропонує вживати термін «кризова дипломатія», який означає діяльність, спрямовану на зменшення рівня напруженості в умовах кризи чи конфлікту.

Останнім часом все більшу увагу надають не просто зменшенню рівня напруженості, а, насамперед, попередженню розвитку конфліктних та кризових ситуацій у світі. Це так звана превентивна дипломатія. Вперше вона дістала своє відображення в одній iз доповідей колишнього Генсека ООН Б. Бутроса-Галі на Генеральній асамблеї ООН від 17 червня 1992 року № A47/277 - S/24111 під назвою «План для досягнення миру. Превентивна дипломатія, забезпечення та збереження миру» («An Agenda for Peace. Preventive diplomacy, peacemaking and peace keeping»), де було намічено основні напрями миротворчої діяльності ООН. В рамках $\mathrm{OOH}$, АСЕАН розробкою концептуальних підходів до превентивної дипломатії займалися дослідники Е.Меландер та К.Пігаче. Роль превентивної дипломатії зводилася ними до засобу миротворчості, врегулювання конфліктів, вирішення глобальних проблем. У своїх підходах до неї дослідники не робили акценту на проблемі національної безпеки і тим більше зовнішньої політики держави.

За змістом і характером заходи превентивної дипломатії поді- 
ляються на політичні, економічні, дипломатичні, воєнні, гуманітарні. Серед політичних заходів інформаційної безпеки - з'ясування односторонніх та багатосторонніх інтересів шляхом обміну інформацією та проведення переговорів; об'єктивне висвітлення сутності конфліктів та кризових проблем засобами масової комунікації; створення умов для професійної діяльності ЗМК у зонах напруженості для забезпечення достовірною інформацією міжнародного співтовариства і формування відповідної світової думки; інформаційне супроводження політичних (референдумів) та виборчих процесів, аналітичні моніторинги за дотриманням основних прав $\mathrm{i}$ свобод людини; інформаційні контакти 3 опозиційними групами, неурядовими організаціями з метою ефективності досягнення консенсусу між сторонами протиборства. Інформаційні чинники економічних заходів передбачають надання матеріальної та фінансової допомоги вільним і незалежним (опозиційним) засобам масової комунікації, забезпечення інформаційної безпеки національних інституціональних мереж та систем, виявлення економічних факторів впливу на перебіг кризових процесів. Специфіка дипломатичних заходів полягає у вивченні інформації про ситуацію в зоні конфлікту, в інформаційному супроводженні переговорів, в тому числі обміні інформацією дипломатичного характеру, поширенні позиційних матеріалів у міжнародних інформаційних потоках та проведенні інформаційних кампаній в країнах перебування 3 метою інформування дипломатичного корпусу інших країн та міжнародної спільноти про врегулювання конфлікту.

Військовий аспект превентивної дипломатії охоплює обмін інформацією військового призначення, створення запобіжних систем від несанкціонованого втручання в автоматизовані (комп'ютерні) системи управління військами та військовою технікою, проведення навчань 3 інформаційних операцій; забезпечення відновлення демократичних прав і свобод у постконфліктний період. Суто інформаційними факторами превентивної дипломатії вважаються: аналіз багатоаспектних даних про потенційні або триваючі конфлікти, підготовка рекомендацій для прийняття рішень на рівні Ради Безпеки ООН, реалізація ухвалення рішень у формі міжнародних механізмів врегулювання конфліктів, впровадження ідеї толерантності і культури миру в міжнародних відносинах. Практика діяльності ООН зі застосування заходів превентивної дипломатії показала необхідність 
3'ясування як теоретичних, так і прикладних підходів до встановлення глобальної безпеки і сталого миру, зумовила розгляд проблеми інформаційної безпеки на рівні міжнародних універсальних, міжурядових регіональних організацій та національних інститутів [4].

Зауважимо, що відмінною від попередніх є концепція превентивної дипломатії американського дослідника М.Лунда [5]. Згідно 3 нею, превентивною дипломатією є комплекс дій окремої держави, спрямованих на недопущення агресіі, погрози з боку іншого актора міжнародних відносин, а також своєчасне попередження дій іншої сторони, які можуть становити загрозу для національних інтересів даної держави. Ця концепція складається 3 невійськових та військових (прямого та непрямого застосування) елементів [5].

До невійськових елементів дослідник відносить переговори (нівелювання конфліктогенної ситуації, агресивних амбіцій потенційного агресора), санкції (примусові заходи, спрямовані проти держави, діяльність якої є потенційною загрозою національним інтересам), ультиматум (потреба до супротивника, з обмеженням часу на іiї виконання, включає погрозу застосування військової сили), «систему далекого відстеження» (розвідування, збирання інформації про потенційну загрозу, цілі супротивника), «співпрацю 3 іншими акторами міжнародних відносин» (співпраця з союзниками, міжнародними організаціями для здійснення колективної превентивної дипломатії) [5].

Військовими елементами автор концепції вважає елементи непрямого застосування, які передбачають побічне використання жорсткої сили. Серед них М.Лунд виокремлює демонстрацію сили (стримування супротивника від застосування військової сили завдяки міцному військовому потенціалу), «стратегічні сили» (ядерна зброя як фактор стримування агресора), систему ПРО (для захисту території держави від ракетно-ядерного удару). Своєю чергою, військові елементи прямого застосування передбачають безпосереднє застосування жорсткої сили. Вони включають «превентивне розгортання» сил (на території, від якої діє загроза національним інтересам), операції з примусу до миру», (за наявності загрози внутрішньополітичної кризи для союзників), «превентивну присутність» (військові бази в регіонах сфери інтересів), «сили швидкого реагування» (мобільні підрозділи для оперативного створення переваги над противником) [5]. 
Вчений застосовує два критерії визначення ефективності превентивної дипломатії у зовнішній політиці будь-якої великої держави. Перший критерій - «ступінь реалізованості економічних, військових, політичних цілей» - дає змогу співвіднести досягнуті результати від застосування превентивної дипломатії з поставленими цілями. Такий критерій дає змогу кількісно співвіднести реалізовані та нереалізовані цілі держави. Співвідношення здійснюється за конкретними перемінними. Ними виступають результати досягнутих цілей.

Другий критерій - «ступінь відповідності реалізованих цілей ціні здійснення превентивної дипломатії» - визначення ступеня ефективності ії застосування шляхом порівняння відповідності результатів досягнутих цілей з завданими витратами. Перемінними відповідності є результати реалізованих цілей, а також ціна застосування превентивної дипломатії. Результати названих цілей включають прибутки в у.о., а також ступінь реалізованості відповідних цілей [6].

Ще одним варіантом дипломатичної діяльності є іміджева дипломатія. Вона визначається як діяльність держави, спрямована на створення за допомогою засобів масової комунікації іміджу національних інтересів та роз'яснення мети й основних завдань зовнішньої політики країни, а також формування бажаної думки світової громадськості. Медіадипломатія передбачає провадження зовнішньої політики держави за допомогою використання ЗМК для впливу на зарубіжну громадську думку. Публічна дипломатія має на меті цілеспрямоване інформування міжнародної громадськості, спрямована на створення позитивної думки про країну, а також підтримку контактів з іншими народами в сфері освіти і культури [7].

Сьогодні існує такий термін, як «віртуальна» дипломатія соціальні, економічні, політичні відносини, які здійснюються за допомогою електронних пристроїв і не передбачають прямого контакту. Застосування інформаційних технологій під час розв'язання різних питань може відіграти важливу роль.

Віртуальна дипломатія є зовнішньополітичною діяльністю, яка охоплює прийняття рішень, координацію, комунікацію, здійснювану за допомогою інформаційних та комунікаційних технологій. Це, насамперед, методи, технології та інструментарій інформаційного впливу на світову громадськість, що мають своєю передумо- 
вою зміну пріоритетів у діяльності зовнішньополітичних дипломатичних установ.

Віртуальна дипломатія є порівняно новим явищем у сфері міжнародних відносин. Тому існує потреба у з'ясуванні законів та закономірностей у даній галузі знань, а це зумовлює теоретичне значення результатів проведеного дослідження.

У своїй науковій роботі «Віртуальна дипломатія. Дипломатія цифрової епохи» О.М.Греч зазначає, що «інформаційні системи підтримки переговорів можуть стати в нагоді на різних етапах переговорного процесу» [8].

Однією 3 форм віртуальної дипломатії є твітер-дипломатія. Вона спричинила революцію у царині дипломатичних відносин, забезпечивши доступ до ширшої аудиторії, а також охопивши всі три рівні дипломатії: найвищий рівень лідерства, який становлять військові та політичні керівники, а також офіційні дипломати; середній рівень - НУО, журналісти та представники академічних інституцій; нижчий рівень - пересічні громадяни та лідери місцевих громад.

Держдеп США окреслює Твітер-дипломатію як форму традиційної дипломатії, яка використовує технології та мережі XXI століття для розв'язання зовнішньополітичних завдань. Це визначення можна поділити на дві основні частини: по-перше, Твітердипломатія відрізняється від традиційної дипломатії переважно тим, що застосовує інші засоби - зокрема, соціальні медіа (Фейсбук та Твітер), програмне забезпечення для інтернет-телефонії (Skype), відеоканали (на сьогодні найпопулярнішим є Youtube). По-друге, Твітер-дипломатія не відмежовується від традиційних форм дипломатичних відносин і не є їх замінником, а, скоріше, потужним і вагомим доповненням, здатним поліпшити та прискорити дипломатиці відносини, а також розширити їх рамки [9].

Твітер-дипломатія суттєво поліпшує взаємозв'язки в усьому світі та надає дипломатам і міністерствам закордонних справ інструменти для побудови власних систем електронних комунікацій iз закордонними підрозділами, а також посольств із консульствами. Її потенціал у побудові комплексу вертикальних та горизонтальних цифрових мереж достатньо ефективно використовується Державним департаментом США, що започаткував важливу ініціативу з поширенню е-дипломатії шляхом іï інтеграції у роботу американських, посольств та консульств. Наочним прикладом 
впровадження цієї ініціативи американськими дипломатами може слугувати проект посольства США у Туреччині, яке організувало цифрові відеоконференції з методу, об'єднання представників усіх чотирьох дипломатичних та консульських установ США у Туреччині та забезпечення координації їхньої роботи у країні. 3 метою формулювання єдиної політики посольство організує регулярні наради з військових, правозахисних та економічних питань [10].

Актуальним прикладом $є$ веб-майданчик саміту «великої двадцятки» у Лондоні. Він відіграв важливу роль у формуванні громадської думки навколо вищезазначеної події в усьому світі. Британські дипломати стверджують, що їхня віртуальна присутність на саміті дозволила «урядові Великої Британії спостерігати за тим, як різноманітні спільноти реагують на ідеї, що виносяться на обговорення». Потенціал е-дипломатії в наданні інструментів для створення подібних віртуальних платформ може бути використаний Україною під час іiі головування в ОБСС 3 метою донесення певних ідей та сигналів як до громадян, так і до міжнародної спільноти, а також для розробки офіційної позиції та іiі формування за участі широкої аудиторії. I в цьому контексті створення офіційної сторінки головування України в ОБСС у Фейсбук було б кроком у правильному напрямі [9].

Інший прагматичний підхід - використання Твітер-дипломатії як платформи для здійснення міжнародної політики країни та побудови міцних дипломатичних відносин. Важливість та корисність інструментів електронної дипломатії для сприяння міждержавної співпраці можна побачити на прикладах проектів Державного департаменту. Так, вони об'єдналися з мексиканськими чиновниками та створили анонімну мобільну гарячу лінію у Хуаресі - місті, спустошеному конфліктами між наркобаронами. Крім того, Вашингтон спільно з Боготою розробив онлайн-мапу протипіхотних мінних полів на територіях, які найбільше постраждали від громадянської війни. Нарешті, чимало зусиль було докладено до запровадження мобільних платіжних систем у охопленій голодом Східній Африці. Отже, електронна дипломатія забезпечує учасників корисними інструментами для провадження міжнародної політики в сучасному, динамічному та взаємопов'язаному світі. Тому ігнорування цієї нової форми дипломатичних відносин означає відмову від їх модернізації та створює загрозу міжнародної ізоляції країн. 
Ця загроза постає ще більш актуальною саме тому, що сьогодні практично всі країни втягнуті в процес формування ефективної моделі майбутньої архітектури світу, пов'язаної, своєю чергою, зі становленням нового багатополярного світового порядку. Йдеться про актуальне завдання зі створення такої системи міжнародних відносин, яка здатна підвищити керованість процесами світового розвитку в цілому й одночасно гарантувати надійну безпеку кожному члену міжнародної спільноти. Тому немає іншого вибору, крім як змінити геополітичну структуру світу, щоб охопити цими змінами більшу кількість сучасних демократичних держав і відтак відкрити шляхи широкому міжнародному співробітництву [11].

Саме на це кількома роками раніше звертав увагу і Г.Кіссинджер. Вчений писав: «Сьогодні вестфальський порядок переживає системну кризу. Його принципи оскаржуються, хоча прийнятну альтернативу ще належить відшукати. Не тільки Сполучені Штати, а й багато європейських держав відкидають принцип невтручання у внутрішні справи інших країн на користь ідей гуманітарної інтервенції або втручання на основі всесвітньої юрисдикції. У вересні 2000 р. на саміті ООН цей підхід був схвалений і підтриманий багатьма іншими державами» [12].

На думку А.Куліджанішвілі, «основною характеристикою процесу глобалізації, що відбувається в сучасному світі, є екстраполяція ліберально-демократичних цінностей на всі регіони без винятку. Це означає, що політичні, економічні, правові та ін. системи всіх країн світу стають ідентичними і взаємозалежність держав досягає небувалих масштабів. До цього часу народи та культури ніколи не були такі залежні один від одного. Проблеми, що виникають у будь-якій точці світу, миттєво позначаються на всьому світі. Процес глобалізації та гомогенізації сприяє створенню єдиного світового співтовариства, в якому формуються єдині норми, інститути та культурні цінності» [13].

Основною тенденцією сучасного типу суспільного історичного розвитку, який відповідає умовам глобалізації, є об'єднання окремих країн, регіонів та континентів у нову загальнопланетарну реальність. Згідно з цим, увесь світ розглядається як «глобальна загальнолюдська реальність, яка базується на збереженні спадкоємності цивілізаційного розвитку, шляхом постійного здійснення унікально-одиничного, регіонально-особливого, попри безпосереднє породження 
цивілізацією багатоманітних, суперечливих диференцій, відмінностей, за умов їх протистояння, в яких гинули окремі цивілізаційні форми і водночас виживали цілі цивілізації» [14].

«Глобалізація - попри всю іï неминучість, - продовжує таке розуміння ситуації Г.Кіссинджер, - може призвести і до посилення гнітючого відчуття безсилля, оскільки рішення, що впливають на долі мільйонів, виходять 3-під контролю місцевої влади. Виникає небезпека того, що сучасні політики можуть не впоратися 3 витонченим характером економіки і технології» [12].

При цьому жодна із держав світу сьогодні не може залишитись осторонь глобальних інтеграційних процесів, оскільки ритм сучасної геополітики зобов'язує кожну 3 них синхронізуватись із сучасними умовами розвитку. Такими сучасними умовами є глобальна інтеграція, яка вимагає від держав включатись у загальнопланетарний простір на умовах реалізації спільних геополітичних потреб та інтересів. Відповідно до цього, основною метою глобальної інтеграції має бути реалізація спільних інтересів шляхом досягнення геостратегічного консенсусу та збереження національної ідентичності [15].

Отже сутність глобальної інтеграції якраз і полягає в тому, щоб спільними зусиллями забезпечити формування та розвиток єдиного соціально-економічного, політичного та культурного простору.

\section{ЛIТЕРАТУРА}

1. Гуменюк Б. Дипломатія доби глобалізації: нові виклики та завдання. Світогляд. - 2009. - № 1. - С. 23-33.

2. Фліссак К.А. Глобалізація і нові виклики економічної дипломатії [Електронний ресурс] - Режим доступу до ресурсу : http://soskin.info/ea/ 2012/1 -2/20124.html

3. «Щодо шляхів вдосконалення організації роботи в галузі економічної дипломатії: стратегічні аспекти». Аналітична записка [Електронний ресурс]. - Режим доступу до ресурсу : http:/www.niss.gov.ua/articles/975/

4. Галі Б. Порядок денний для миру. Превентивна дипломатія, миротворчість і підтримання миру. - Нью-Йорк, ООН, 1992. - 500 с.

5. Lunde $M$. Undertaking preventive diplomacy [Електронний ресурс] - Peжим доступу : http://www.foreignaffairs.com/articles/51214/michael-slunde/undertaking-preventive-diplomacy

6. Кухалейшвілі Г.Р. Критерії ефективності превентивної демократії в 
сучасній системі міжнародних відносин [Електронний ресурс] - Режим доступу до ресурсу : http://istfak.org,ua/tendentsii-rozvytku-suchasnoisystemy-mizhnarodnykh-vidnosyn-ta-svitovoho-politychnoho-protsesu/ 183-protsesy-rehionalizatsii/577-kryteriyi-efektyvnosti-preventynoyidyplomatiyi-v-suchasniy-systemi-mizhnarodnykh-vidnosyn

7. Швець О. Формування політичного іміджу України у міжнародному інформаційному просторі [Електронний ресурс] - Режим доступу до pecypcy : http://search.ukr.net/cache/?q=cache:nd0nN-xsKJ4J:http://irbisnbuv.gov,ua/bin/irbis64r_81/cgiirbis_64.exe?C21COM=2\&I21DBN=ARD $\& P 21 D B N=A R D \& Z 21 I \bar{D}=\& I m a g e$ file_name=DOC/2006/06sovmip.zip $\&$ IMAGE_FILE_DOWNLOAD $=1$

8. Grech $O$. Virtual Diplomacy. Diplomacy of the Digital Age. - University of Malta, 2006. - P.37. - [Cited 2-Apr-2012] - Режим доступу до ресурcy : http://uscpublicdiplomacy.org/pdfs/Grech.pdf

9. Літра Л. Твітер-дипломатія: Як новітні технології можуть посилити міжнародні позиції України? [Електронний ресурс] - Режим доступу до ресурсу: http://iwp.org.ua/img/policy_brif_1_0.1_23_ok.pdf

10. Leading Through Civilian Power: Quadrennial Diplomacy and Development Review (2010). The State Department of the United Statesof America [Online]. - Режим доступу до ресурсу: http:/www.state.gov/documents/ organization/153108.pdf

11. Зленко A. Переосмислюючи зовнішню політику України: важкий шлях до досягнення консенсусу [Електронний ресурс] // Дзеркало тижня. Україна. - №6. - 19 лютого 2010. - Режим доступу до ресурсу : http://gazeta.dt.ua/POLITICS/pereosmislyuyuchi_zovnishnyu_politiku_ukr ayini vazhkiy_shlyah_do_dosyagnennya_konsensusu.html

12. Киссинджер Г. Нужна ли Америке внешняя политика? [Електронный pecypc]. - М., 2002. - С. 1-17, 235-261. - Режим доступу до ресурсу : http://lib.chdu.edu.ua/pdf/posibnuku/307/43.pdf

13. Человек: соотношение национального и общечеловеческого : Сб. материалов междунар. симпозиума (г.Зугдиди, Грузия, 19-20 мая 2004 г.), вып. 2 / Под ред. В.В.Парцвания. - СПб., 2004. - Режим доступа : http://anthropology.ru/ru/texts/kvarats_va/mannt_14.html

14. Соловьев В. Сочинения : В 2 т. - М., 1988. - Т. $\overline{1} .-563$ с.

15. Войтович P.В. Глобальна інтеграція як нова форма суспільного розвитку [Електронний ресурс] - Режим доступу до ресурсу: http://www.academy.gov.ua/ej/ej 12/txts/10vrvfsr.pdf 
Григор О. Багатостороння дипломатія як чинник урегулювання міжнародних конфліктів і кризових ситуацій.

Сучасні міжнародні відносини переживають глибокі трансформації, тому тісно пов'язана з ними дипломатія також зазнає грунтовних змін. ії функції, які раніше були фактично прерогативою зовнішньополітичних відомств і здійснювалися переважно посольствами, нині реалізуються через численні державні та недержавні канали. Отже, пов'язана з процесами глобалізації перебудова міжнародних відносин, вихід на світову арену недержавних учасників міжнародних стосунків ставлять перед дипломатією завдання іiї активного залучення в процес створення нового світового порядку. Водночас силові розв'язання міжнародних проблем виявляються все більш недієвими та небезпечними. В цих умовах саме багатостороння дипломатія є ефективним механізмом урегулювання міжнародних конфліктів і кризових ситуацій.

Ключові слова: людина, політика, культура, глобалізація, міжнародні відносини, багатостороння дипломатія.

Григор О. Многосторонняя дипломатия как фактор урегулирования международных конфликтов и кризисных ситуачий.

Современные международные отношения переживают глубокие трансформации, поэтому тесно связанная с ними дипломатия также испытывает глубокие изменения. Ее функции, которые ранее были фактически прерогативой внешнеполитических ведомств и осуществлялись преимущественно посольствами, сейчас реализуются через многочисленные государственные и негосударственные каналы. Итак, связанная с процессами глобализации перестройка международных отношений, выход на мировую арену негосударственных участников международных отношении ставят перед дипломатией задачу ее активного вовлечения в процесс создания нового мирового порядка. Одновременно силовые решения международных проблем оказываются все более недейственными и опасными. В этих условиях именно многосторонняя дипломатия является эффективным механизмом урегулирования международных конфликтов и кризисных ситуаций.

Ключевые слова: человек, политика, культура, глобализация, международные отношения, многосторонняя дипломатия.

Grygor O. Multilateral diplomacy as a factor of settlement of international conflicts and crises.

Modern international relations are going through a profound transformation, so closely related to them diplomacy is also undergoing profound changes. Its functions that previously were actually the prerogative of foreign ministries and embassies, now are implemented through multiple public and private

ISSN2078-8142 Мультиверсум. Філософський альманах.-2015.-Випуск 3-4(141-142) 57 
channels. Thus, globalization, associated with the processes of restructuring of international relations, access to the world stage non-state actors of international relations diplomacy objectives set a goal of its active involvement in the process of creating a new world order. At the same time solution of international problems with force is increasingly ineffective and dangerous. In these circumstances, multilateral diplomacy is an effective mechanism for settling international conflicts and crisis situations.

Key words: human being, politics, culture, globalization, international relations, multilateral diplomacy. 